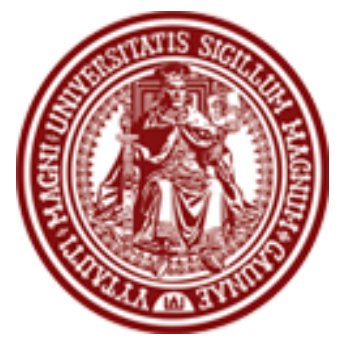

BALTIC JOURNAL OF LAW \& POLITICS

VOLUME 4, NUMBER 2 (2011)

ISSN 2029-0454

http://www.versita.com/bjlp

Cit.: Baltic Journal of Law \& Politics 4:2 (2011): 154-186

DOI: $10.2478 / \mathrm{v} 10076-011-0016-1$

\title{
CAN A SENIOR CIVIL SERVANT ADAPT TO MANAGING BY CONTRACT? REFORM AND CIVIL SERVANTS' PREFERENCES IN LITHUANIAN GOVERNMENT
}

\author{
Remigijus Civinskas \\ Associate Professor; Dr. \\ Vytautas Magnus University, Faculty of Political Sciences and Diplomacy \\ (Lithuania) \\ Contact information \\ Address: S. Daukanto str. 28, LT-44246 Kaunas, Lithuania \\ Phone: + 37037327867 \\ E-mail address: r.civinskas@pmdf.vdu.It
}

Received: November 29, 2011; reviews: 2; accepted: December 22, 2011.

\begin{abstract}
This article seeks to explain the attitudes of civil servants to the preparation of redesigning the civil service system. The starting point for this study is the perplexing point that the plans to reform the Lithuanian civil service system, which was designed to enhance the influence and role of top managers, resulted in the civil servants themselves as the plan's most conspicuous opponents. The article provides explanations to this puzzling situation, drawing on contractualization as the radical reform model or public management model. An attempt is made to find some support for performance contracts, as well as the objectives of rotation implementation and the creation of a higher civil service system. The article argues that civil servants may regard contracts and other managerial elements as a way of realizing other objectives in the reform that they value.
\end{abstract}

\section{KEYWORDS}

Civil service reform, public management reform, contractual regimes in civil service, contracting in civil service 


\section{NOTE}

This article is prepared on the basis of the research project "Public Service Reform in the light of Good Governance (Participatory Governance)" (contract no. MIP - 33/2010), financed by the Research Council of Lithuania. 


\section{INTRODUCTION}

As the Governments implement public sector reforms, opposition factors are faced that sometimes become difficult obstacles or even traps for reforms. One of negative factors related to the implementation of reforms is related to the civil servants' opposition to the reforms. This is not a typical phenomenon, but it does happen and is known for academics as a part of preparation and implementation of reform ${ }^{1}$. Its reasons, nature and the interests of civil servants are clearer when their opposition is towards the preparation and implementation of civil service reform. This reform obstacle is peculiar because civil servants have almost unrestricted information access and the competencies of technical expertise in contrast to other reform opposition groups. Besides, a part of them quite often become reform organizers. Of course, the participation of civil servants in contemporary reform preparation and, partly, implementation processes is eliminated by involving external experts, creating specialized and independent agencies which manage/coordinate reform implementation, or decreasing the level of bureaucratic discretion by other means. ${ }^{2}$

But there are perhaps deeper causes for opposition to reforms. Some researchers explain resistance to reforms by the terms of administrative traditions or institutional cultures. ${ }^{3}$ Administration tradition works as a predisposition to political-administrative decisions. It can also comprise the intentions to simulate, imitate and direct activities towards a different direction and also stop changes. Despite the existing transformations, Saulius Pivoras emphasized the continuation of the Soviet tradition while analyzing the characteristics of Lithuanian bureaucracy from this perspective. ${ }^{4}$ Another argument expressed by Vitalis Nakrošis also conforms to this category of predisposition(s): "The decisions of new public management doctrine often are not suitable for Lithuania." ${ }^{5}$ This is due first of all

1 Christopher Pollitt and Geert Bouckaert, Public Management Reform: A Comparative Analysis-New Public Management, Governance, and the Neo-Weberian State (Oxford: Oxford University Press, 2011), p. 25, 32; Edoardo Ongaro, Public Management Reform and Modernization, Trajectories of Administrative Change in Italy, France, Greece, Portugal and Spain (Cheltenham \& Northampton: Edward Elgar, 2009), p. 256.

2 Francesca Gains, Peter John, and Gerry Stoker, "When Do Bureaucrats Prefer Strong Political Principals? Institutional Reform and Bureaucratic Preferences in English Local Government," British Journal of Politics and International Relations 10(4) (2008): 650-652; John Huber and Charles Shipan, Deliberate Discretion? The Institutional Foundations of Bureaucratic Autonomy (Cambridge: Cambridge University Press, 2002), p. 221-222.

3 B. Guy Peters and Martin Painter, "Conclusion: Administrative Traditions in an Era of Administrative Change": 237; in: B. Guy Peters, Martin Painter, eds., Tradition and Public Administration (New York \& Houndmills: Palgrave Macmillan, 2010).

${ }^{4}$ Saulius Pivoras, "Post-Soviet Transformation of Bureaucracy in Lithuania: Main Features and Trends," Baltic Journal of Law and Politics Vol. 1 (2008): 123-125.

5 Vitalis Nakrošis, "Viešojo valdymo reformos Lietuvoje: kodèl ir kuo reikia pakeisti Naujaja viešaja vadyba" (Reforms of Public Administration in Lithuania: Why and by whom the New Public Management Has to Be Replaced), Politologija 1 (2011): 68. 
too little empirical proof is provided and also the conclusions of comparative studies are taken as a basis. In fact, these culturally determined positions limit the analysis of the phenomenon and are more suitable to its genesis rather than the analysis of contemporary reforms.

Thus while analyzing reforms, the administrative traditions of a culture are supplemented or changed by the analysis of institutional or personal actors or the existing favorable circumstances. ${ }^{6}$ This research on institutionalist, interactive action or principal-agent relationship emphasizes that opposition to reforms and other political administrative interaction are conditioned by the structure of the institution, interests of actors, conjunction situations, type of politicaladministrative relationship, etc. ${ }^{7}$ This analytical perspective is suitable for research on reform preparation and implementation dynamics, and interaction between institutional and individual actors. It can also include reform obstacles and even traps, i.e. the identification of final stages of the reform. This is topical not only in the analysis of reform opposition factors but also radical reforms according to their aims, content and type of preparation and implementation.

The analysis of content and aims of radical reforms often leads to normative and empirically ungrounded interpretations. For example, research on the application of management reform models is often based on preconceptions of opposing researchers. These contrasting opinions are determined by different ideological attitudes, paradigmatic points of view (in the boundaries of public administration) and methodologically complicated assessments of the reform process and results. $^{8}$ However, adequate conceptual and methodological approaches and a neutral point of view can contribute to objective analysis of this phenomenon.

As concerns other problematics, e.g. the opposition to reforms by civil servants and administrative elites, it can be noted that this phenomenon has been analyzed since the 1980s. The research focused on such aspects as inertia and inflexibility in the reform implementation, as well as simulation/fraudulence. ${ }^{9}$ However, these studies lack empirical research that reveals the scope and problems

\footnotetext{
${ }^{6}$ B. Guy Peters, "What Works? The Antiphons of Administrative Reforms": 78-82; in: B. Guy Peters and Donald Savoie, eds., Taking Stock: Assessing Public Sector Reform (Montreal and Kingston: Canadian Centre for Management Development and McGill-Queen's University Press, 1998).

7 Michael Howlett, "Administrative Styles and the Limits of Administrative Reform: A Neo-Institutional Analysis of Administrative Culture," Canadian Public Administration 46 (2003): 473-478.

8 Robert Pyper and June Burnham, "The British Civil Service: Perspectives on 'Decline' and 'Modernisation'," The British Journal of Politics \& International Relations 13 (2011): 190-191.

9 Christopher Hood and Martin Lodge, The Politics of Public Service Bargains: Reward, Competency, Loyalty - and Blame (Oxford: Oxford University Press, 2006), p.158-160; Robert F. Durant and Jerome S. Legge, "Politics, Public Opinion and Privatization in France: Assessing the Calculus of Consent for Market Reforms," Public Administration Review 62 (3) (2002): 310-311.
} 
of the phenomenon. ${ }^{10}$ Factors of opposition towards reforms have hardly been analyzed. However, some attention has been paid to the possible problem of civil service politicization (since 2004 Lithuania has been ascribed to the group of the least politicized systems in Eastern and Middle Europe), ways of reform implementation and choice of models ${ }^{11}$.

The aim of the present article is to reveal the points of view of civil servants and administrative elites towards civil service contracts as the most radical element in the Lithuanian civil service reform. This article analyses the concept of contracts and peculiarities of their use in the reform of civil service systems. The opinions of Lithuanian civil servants and administrative elites are also going to be analyzed with respect to service contract use.

\section{CONTRACTS IN CIVIL SERVICE}

While studying reforms of civil service, most authors focus on the changes in Anglo-Saxon systems. They are most often related to the application of the elements of the New Public Management doctrine. Most studies which analyzed civil service transformations in the UK, New Zealand, the USA and Australia, contain the above mentioned themes. Mainly these works reveal the aims, models and contents are revealed, as well as discussing different aspects of results. ${ }^{12}$ The papers state that the introduction of fixed-term staff contracts and performance contracts, as well as other elements, totally changed state service systems and created much more flexibility and mobility. In addition, the systems themselves have become more open, flexible and result-oriented after the implementation of ambitious reforms ${ }^{13}$. However, not all academics' evaluations are positive. Some researchers note that the contracts adapted by the top civil servants abolished administrative responsibility and influenced politicization of selection and system fragmentation.

\footnotetext{
${ }^{10}$ Elissabeta Gualmini, "Restructuring Weberian bureaucracy: comparing managerial reforms in Europe and the United States," Public Administration 86 (1), (2008): 78-94; Daniela Cristofoli, Greta Nasi, Alex Turrini, and Giovanni Valotti, "Civil Service Reforms in Italy: The Importance of External Endorsement and Administrative Leadership," Governance 24 (2) (2011): 261-262.

${ }_{11}$ Jan-Hinrik Meyer-Sahling, Post-Accession Sustainability of Civil Service Reform in Central and Eastern Europe (Paris: OECD-SIGMA Publications, 2009), p. 76; Vitalis Nakrošis, supra note 5: 93-94.

${ }_{12}$ Carolyn Ban, "The Changing Role of the Human Resource Office": 48-49; in: Stephen E. Condrey, ed., Handbook of Human Resource Management in Government (San Francisco: Jossey Bass, 2005); B. Guy Peters, "Administrative Traditions and the Anglo-American Democracies": 14; in: John Halligan, ed., Civil Service Systems in Anglo-American Countries (Cheltenham: Edward Elgar, 2003); John Halligan, "The Australian Public Service: Redefining Boundaries, Administrative Traditions and the Anglo-American Democracies": 87- 88; in: John Halligan, ed., Civil Service Systems in Anglo-American Countries (Cheltenham: Edward Elgar, 2003); Allen Schick, "The Spirit of Reform: Managing the New Zealand State Sector in a Time of Change," A Report Prepared for the State Services Commission and The Treasury, New Zealand (August 1996) // http://www.thedplg.gov.za/subwebsites/igr/docs/Publications/Pub5.pdf (accessed November 11, 2008). 13 Christopher Hood, "Individualized Contracts for Top Public Servants: Copying Business, PathDependent Political Re-Engineering-or Trobriand Cricket?" Governance 11 (1998): 460; John Halligan, "Anglo-American Systems: Easy Diffusion":58; in: Jos C.N. Raadschelders, Theo Toonen, and Frits M. Van der Meer, eds., The Civil Service in the 21st century: comparative perspectives (Basingstoke: Palgrave Macmillan, 2007).
} 
This division of opinions and conditions is conditioned by the supporters and critics of New Public Management, which has lasted for several years. However, theoretical and methodological approaches are very significant, and they form the basis on which the reform evaluation is performed. Despite these opinions, it is possible to state that the critics' voices are clearly more grounded.

There are quite a lot of scientific studies related to contract adaptation in the transformations of public service. Publications by Christopher Hood, Per Laegreid, Annie Hondeghem and Line Putseys, which are devoted to contractualisation of top civil servants, are all noteworthy. ${ }^{14}$ These public administration researchers have studied transformations in Anglo-Saxon and other Western European states by using a comparative method. Their conclusions reveal the disadvantages of reforms and negative consequences for systems related to the following: 1) civil servant's responsibility is not clearly defined; 2) costs of employment and enabling mobility are big; 3) difficulties in employees' monitoring and assessing their correspondence to contract commitments. Even a proponent of contract relationship, Ch. Hood, emphasizes that the use of contract relationship has limitations because of overlapping responsibilities and constant threats. As the example of New Zealand shows, public managers employed by contracts managed to benefit from the system. For example, they did not wait for the end of the agreed term and resigned in order to participate in another useful competition. Also the institutions allotted severance pays for those who left the office. Finally, as noted by R. C. Mascarenhas, the new managerial culture formed the 'we-they' contrast (because of salary differences foreseen in the contracts), which was not expressed in earlier civil service. ${ }^{15}$

Empirical studies also analyze the use of contracts in continental Europe. A number of authors have analyzed the use of short-term contracts in Belgium, Portugal, Greece, France, Italy, the Netherlands, and Denmark. These empirical studies are significant not only for their conclusions, but also because of insights related to possible approaches. The main studies are oriented towards the research of radical and management-type reforms (the cases of Belgium, the Netherlands, Denmark and Switzerland), while in other countries reform cases are analyzed as one of many elements.

\footnotetext{
14 Per Lægreid, "Top Civil Servants under Contract. Public Administration," Public Administration 4 (2000): 879-896; Line Putseys and Annie Hondeghem, "Contractualisation of Top Civil Servants: an Iinternational Comparative Research," Annual Meeting of the European Group of Public Administration (EGPA) (September 2003) // http://soc.kuleuven.be/io/pubpdf/IO06060003.pdf (accessed October 11, 2011).

${ }_{15}$ R.C. Mascarenhas, "The New Zealand Public Service: National Identity and International Reform": 125; in: Jos C.N. Raadschelders, Theo Toonen, and Frits M. Van der Meer, eds., The Civil Service in the $21^{\text {st }}$ Century: Comparative Perspectives (Basingstoke: Palgrave Macmillan, 2007).
} 
While analyzing civil service reforms in Belgium in the 1990s, researchers note that they are based on the ideas of New Public Management, and fixed-term contracts (two tenures for 6 years) formed the basis for these reforms. After almost a decade, the situation changed. In 2001, the Belgium Government decided to transform the relationship between politicians and senior civil servants on the basis of operational contracts. ${ }^{16}$ Belgian researchers note that the results of the reforms were not apparent because the reform package was fragmentary, and its implementation was not consistent. ${ }^{17}$ The fact that the system is not finished is confirmed by the poll that was carried out several years ago by a group of researchers; the results show that Belgium federal civil service moves towards activity management but there is no total distancing from rule-based service. ${ }^{18}$

Different conclusions are reached in the studies which analyze the systems of top civil servants in the Netherlands and Denmark. A reform started in 1995 in the Netherlands and comprised 740 (now around 800 ) top civil servants (the so-called top civil service 'Algement Bestuursdienst'). The aim of the reform was to increase mobility and management professionalism of senior civil servants. The reform was of a managerial type. It also introduced a career system in the Dutch civil service. Some researchers view the results and consequences of this reform positively. ${ }^{19}$ One of the peculiarities of the Netherlands is flexibility. For instance, the model of individual performance contract is only exemplary for the Ministries. Most of them sign contracts with officials choosing acceptable elements of this model. ${ }^{20}$

The use of performance contracts for top Danish civil servants was much smaller in scope in comparison with Belgium and the Netherlands. Performance contracts, the use of which is not obligatory, are made only with heads of agencies. ${ }^{21}$ Researchers also note that the nature of contract use has changed over fifteen years. ${ }^{22}$ In the Danish civil service not only narrow performance contracts,

16 Anne Ketelaar, Nick Manning, and Edouard Turkisch, "Performance-Based Arrangements for Senior Civil Servants OECD and other Country Experiences," OECD Working Papers on Public Governance Vol. 5 (2007): 12-18.

17 Guido Dierickx, "Senior Civil Servants and Bureaucratic Change in Belgium," Governance 16 (2003): 320-330; Marleen Brans and Annie Hondeghem, "The Senior Civil Service in Belgium": 141-143; in: Edward C. Page and Vincent Wright, eds., Bureaucratic Elites in Western European States. A Comparative Analysis of Top Officials (Oxford: Oxford University Press, 2002).

${ }^{18}$ Karolien Van Dorpe, Annie Hondeghem, Montuelle Caroline, and Christian de Visscher, "Assessing the Belgian Mandate System from an International Comparative Perspective," ESPA Conference, Rotterdam (September 3-6, 2009) // http://soc.kuleuven.be/io/egpa/HRM/rotterdam/Van\%20Dorpe-HondeghemMontuelle\&De\%20Visscher2008.pdf (accessed May 23, 2011).

19 Trui Steen and Frits M. Van der Meer, "Dutch Civil Service Leadership: Torn between Managerial and Policy-Oriented Leadership Roles": 100-101; in: Jeffrey A. Raffel, Peter Leisink, and Anthony Middlebrooks, eds., Public Sector Leadership: International Challenges and Perspectives (Cheltenham: Edward Elgar Publishing, 2009).

${ }^{20}$ Anne Ketelaar, Nick Manning, and Edouard Turkisch, supra note 16: 46.

${ }^{21}$ Peter Pedersen, Hanne Sorensen, and Jakob Vestergaard, "Public Service Performance Contracting in Denmark," OECD (1999) // http://www.oecd.org/dataoecd/10/62/1902729.pdf (accessed May 10, 2011).

22 Anne Binderkrantz and Jorgen Christensen, "Governing Danish Agencies by Contract: From Negotiated Freedom to the Shadow of Hierarchy," Journal of Public Policy 29 (2009): 73-77. 
but also fixed staff contracts are used. Staff contracts started to be used in central management bodies and municipalities beginning in 1991. According to Jorgen Christensen, the consequence of these reforms is that most public managers (former civil servants) and public sector employees work under fixed contracts. ${ }^{23}$ Only departments of courts, police and prosecution service are based on the classical concept of civil service. Thus one can state that new public management reforms fundamentally transformed the Danish civil service system. The reform implementation process in Denmark differed from the radical reform model in New Zealand and the UK. There the extent of contracts in personnel management was gradually increased. ${ }^{24}$

While analyzing the use of contracts in civil service, another analysis aspect is the change in the status of civil servants who work under personnel contracts. A substantial part of civil service in most European countries is formed of civil servants who work under personnel contracts. The greatest number work in the education, health, social protection and culture sectors. They also form a personnel part in central and subnational institutions. For example, one third of employees work in the institutions subordinate to Spanish central government ${ }^{25}$, while in Belgian federal institutions the number reaches 20 percent. ${ }^{26}$ The relative number of employees who belong to this category is even larger in regions and municipalities. The number of such civil servants has significantly increased in French municipalities after liberalization of legal regulations of municipal civil servants. ${ }^{27}$ According to research, implemented reforms in France, Spain and Italy created the category of municipal public managers and even different categories of duties, such as project, staff or personal service managers. ${ }^{28}$ It can be noted that a part of these reforms started only five years ago and are not related to ideological incentives of new public management. For example, demographic reasons cause the liberalization of employment in France.

The analysis of contract use in staff reforms reveals not only the contents of reform packages, aims and peculiarities of use, but also negative effects. For instance, Isabel Corte-Real's conclusion that the employment of top public managers (civil servants employed under fixed-term contracts) was politicized,

23 Jorgen Christensen, "Danish Public Management Reform before and after NPM": 291-293; in: Shaun Goldfinch and Joe L. Wallis, eds., International Handbook Of Public Management Reform (Cheltenham: Edward Elgar Publishing. 2009).

24 Robert Gregory and Jorgen Christensen, "Similar Ends, Differing Means: Contractualism and Civil Service Reform in Denmark and New Zealand," Governance 17 (2004): 61-75.

25 Salvador Parrado, "Failed Policies but Institutional Innovation through 'Layering' and 'Diffusion' in Spanish Central Administration," International Journal of Public Sector Management 21 (2008): 208.

${ }^{26}$ Guido Dierickx, supra note 17: 321-327.

27 Alistair Cole and Jones Glyn, "Reshaping the State: Administrative Reform and New Public Management in France," Governance 18 (2005): 568-569.

${ }^{28}$ Luc Rouban, "Reform Without Doctrine: Public Management in France," International Journal of Public Sector Management 21 (2008): 142. 
created clientele systems and did not provide a desirable result. ${ }^{29}$ A similar conclusion was made by researcher Calliope Spanou, who analyzed the use of average term contracts for Greek enterprises and heads of different institutions. ${ }^{30}$ However, positive impacts can be noted in addition to the negative ones. This is especially noticeable in the implementation of reforms in Denmark. It adapted the radical model of New Zealand and chose collaboration (constant coordination of contracts with trade unions) and gradual implementation method. This allowed avoiding opposition from civil servants, politicians and the society, as well as other negative consequences. ${ }^{31}$

The use of contracts is not a part of reform packages only in Western countries. Various attempts are apparent in Eastern and Middle European countries. For instance, Latvia used performance contracts for a part of civil servants in 1997 (in 2009 they were signed by 10 per cent of civil servants in leading positions). They formed the basis for payment of a more than 100 percent premium. A similar system was operating in Hungary in 1997-2001; nowadays it is operating in Slovakia. However, according to Tony Verheijen, such attempts are exceptions in reform contexts. ${ }^{32}$ It should also be noted that the attempts to create higher civil services in Slovakia and Hungary were not successful. ${ }^{33}$

Generalizing reform studies of contract use, one can note that they reveal the transformations of several decades related to the implementations of models based on the ideas of new public management. New public management studies reveal that radical reforms (the UK and New Zealand) changed the systems of civil service by introducing flexibility and result-orientation to human resource management. However, the conclusions of most researchers show that these reforms only partially reached their aims (or these aims were not entirely apparent) and had negative consequences related to a lack of administrative responsibility, high costs of acceptance, and contract monitoring and politicization of civil servants' roles. Academic discourses reveal positive stories in addition to information about reforms in which the failure is outright, or the success otherwise unapparent. Such examples of a positive practice can be related to reforms in Denmark and the Netherlands, where the categories of civil servants and servants employed under fixed contracts were reformed. These reforms were implemented gradually or in

29 Isabel Corte-Real, "Public Management Reform in Portugal: Successes and Failures," International Journal of Public Sector Management 21 (2008): 222-223.

30 Calliope Spanou, "State reform in Greece: responding to old and new challenges," International Journal of Public Sector Management 21 (2008): 157.

31 Robert Gregory and Jorgen Christensen, supra note $24: 61-75$.

32 "Administrative Capacity in the New EU Member StatesThe Limits of Innovation?" Document of the World Bank (December 2006) //

http://siteresources.worldbank.org/INTECA/Resources/EU8_AdminCapacity_Dec06.pdf December 01, 2011); Jan-Hinrik Meyer-Sahling, supra note 11: 50.

(accessed

33 Ibid.: 49. 
several stages and avoided political opposition using dialogue with trade unions (the case of Denmark) and made the systems of civil service apparently more flexible. Truly, these positive epilogues are practically unique in the abundance of European civil service reforms. Use of contracts in the employment of civil servants in Greece and Portugal politicized civil service and created client relationship between politicians and civil servants. The studies of employment under contract carried out during recent years reveal that this personnel management still remains topical. Of course, there is no managerial or ideological pathos in its use and it is difficult to find models of positive practice.

\section{LITHUANIAN CIVIL SERVICE REFORM: BUILDING EFFECTIVE INDIVIDUALIZED CONTRACTS FOR TOP MANAGERS}

Contracts and rotation for senior civil servants, as the most radical elements in state control, appeared in the epicenter of civil service transformations for two reasons. First, political assumptions were favorable for such reforms. At the end of 2008, the Conservative party won the election. It followed neoliberal ideas of public sector transformation and suggested the managerial model of state transformations, as well as implementation of its commitment. ${ }^{34}$ The analysis of the electoral program reveals that the main attempt was to change the career system. Several important means were indicated: 1) fixed term performance contracts between the head of the institution and top managers of departments/agencies; 2) performance contracts between civil servants and their direct heads. They were supplemented by transformations in the areas of civil servant employment, evaluation, selection and senior civil servant rotation. This was conceptualized by the aim of civil service orientation to results. In other words, this was a radical managerial model, where the civil service focus was on results, the basis for which is formed by performance contracts.

Modified political provisions were included into the program of the Government headed by Andrius Kubilius (from November 27, 2008). ${ }^{35}$ It includes the development of the following elements of the civil service system: selection, evaluation, career and responsibility, as well as top civil servant rotation. One can note that a contract is not mentioned in these plans as a specification of transformation means. However, there were quite a lot of indirect allusions to the

\footnotetext{
34 LK (TS) $2008 \mathrm{~m}$. Seimo rinkimu programa 2008-2012 (2008 Election Program of "Homeland Union Lithuanian Christian Democrats" Party) //

http://www.tsajunga.It/index.php/seimo_rinkimu_programa_2008_2012/9081 (accessed November 1, 2011).

35 On the Programme of the Government of the Republic of Lithuania, Resolution of Seimas of the Republic of Lithuania No. XI-52 (December 09, 2008) //

http://www.Irv.It/bylos/vyriausybes/en_15_programa.pdf (accessed November 1, 2011).
} 
principle of result-orientation in this program. It also states the way of implementation. First, the partners of coalition Government had to agree on the provisions and to prepare the conception of the reform on their basis. Smaller coalition partners, right Liberal parties, naturally agreed on the aims of this neoliberal reform. Researcher Vitalis Nakrošis identified this document with decisions of post-New Public Management doctrine in the area of civil service. He also stated that some elements (including contracts) are more related to New Public Management features. ${ }^{36}$

Transformations were indirectly influenced by the economic crisis, which increased at the beginning of 2009. Transformations had to be saving-oriented, and in the case of civil service, the number of employees and salaries had to be decreased. Naturally, development instruments and result-orientation were put aside. Probably because of this, the preparation of the reform document which reveals the aims and means of the reform took longer. This is revealed by the document analysis of the State Improvement Commission (the so-called Sunset commission), which coordinated the Government reform. ${ }^{37}$ The preparation of civil service reform started in spring of 2009. This was done by Ministry of the Interior, which is directly responsible for this transformation. A working group was created in the Ministry, which was responsible for the preparation of action plan according to the program of the Government. However, the process was slow. Sunset commission, which was monitoring and coordinating the reforms, saw this. In the summer of 2009, Kęstutis Masiulis, a member of the Conservative party, Institute of Public Management and Sunset Commission, offered to prepare the guidelines of the reform. In academic and party activities he was already known for radical reform suggestions. ${ }^{38}$ His ideas on state transformation, which indicate contract responsibility of senior civil servants and a remarkable decrease in the number of civil servants, received sharp criticism from some academics. ${ }^{39}$ The head of the Sunset Commission suggested to him that he not interfere in the responsibilities of the Ministry of the Interior and coordinate suggestions about reforms rather than prepare models. ${ }^{40}$ These were internal disagreements and more important reforms

\footnotetext{
${ }^{36}$ Vitalis Nakrošis, supra note 5: 82.

37 Minutes by the Sunset Commission under the Government of the Republic of Lithuania for the year 2009-2011//

http://www.Irv.It/veikla/komisijos/saulelydzio-komisija/komisijos-veikla/ (accessed November 1, 2011).

38 Minutes by the Sunset Commission under the Government of the Republic of Lithuania No. $73-36$ (18)

(June 10, 2011) // http://www.Irv.It/bylos/veikla/komisijos/saulelydzio/protokolas_09_06_10.pdf (accessed November 1, 2011).

39 Klaudijus Maniokas, "Valstybès tarnybos reforma ar jos chunveibiniškas griovimas?" (Civil service Reform or Its Demolition in Hongweibing Style), Delfi.lt (June 1, 2009) //

http://www.delfi.lt/news/ringas/lit/article.php?id=22428924 (accessed October 1, 2011).

40 Minutes by the Sunset Commission, supra note 38; Kęstutis Masiulis, "Saulèlydžio komisijai jau artèja saulèlydis" (Sunset Commission Comes to Its Sunset), Irytas.It (August 8, 2009) [Interview with exmember of Sunset Commission] //
} 
oriented towards saving of resources. Finally, there were big expectations from the establishment of Prime Minister's Service (henceforth, PMS), which had to take the coordination functions of reform preparation and, in fact, preparation functions when the ministries were passive.

Of course, the question of contract use in the civil service did not disappear from the reform agenda. The Department of Civil Service (henceforth DCS), the institution which is directly responsible for the preparation of the main document, was preparing the conception of civil service. In this institution, the point of view towards contracts, assessment according to result and rotation were very reserved, as the data of qualitative interview reveal. ${ }^{41}$ Probably because of this, the Minister of the Interior reacted critically towards passive opportunism and the suggestions to carry out some small corrections of the system rather than implement a radical reform. ${ }^{42}$ Besides, there were both objective and subjective political interests related to the transformations of personalities and subordination of the mentioned institution.

However, his attitudes towards post system model and greater flexibility while dismissing civil servants in fact corresponded to the aims indicated in the state program about the system transformation. The role of the Ministry of the Interior (henceforth, MI) were not clearly defined in the reform preparation, which allowed the PMS, or, more precisely, its working group, to take over the preparation of reform documents. The dynamics of project preparation were conditioned not only by the crossing of institutional and political interests, but also other reforms related to strategic planning, budget formation and transformations of institutional structure. Here the results of senior civil servants and the aspect of contracts were critical to successful implementation (e.g. for the implementation of strategic planning methodology) or important indirectly. ${ }^{43}$

The first reform document, Conception of the Improvement of Civil Service, appeared in the spring of 2010. It describes the general principles of civil service improvement and development guidelines. ${ }^{44}$ The reform organizers planned

http://www.Irytas.It/-12498786351247812444-saul\%C4\%97lyd\%C5\%BEio-komisijai-jau-art\%C4\%97jasaul\%C4\%97lydis.htm (accessed October 1, 2011).

${ }^{41}$ Interview with civil servant, Ministry of the Interior, May 06, 2011.

42 Raimundas Palaitis, "Reikia ne valdyti, o tarnauti" (It Is Necessary to Serve, not to Govern), delfi./t (September 14, 2009) [Personal interview about implementation of civil service reform] //

http://www.delfi.lt/news/daily/lithuania/rpalaitis-reikia-ne-valdyti-o-tarnauti.d?id=24031168 (accessed October 1, 2011).

43 Minutes by the Sunset Commission under the Government of the Republic of Lithuania No. 63-5 (February 11, 2010) //

http://www.Irv.It/bylos/veikla/komisijos/saulelydzio/3_2010-02-11_posèdžio_protokolas.pdf (accessed May 31, 2011); Interview with head of the institution, Office of the Prime Minister, June 20, 2011.

${ }_{44}$ Valstybes tarnybos tobulinimo koncepcija (Civil Service Improvement Conception), Project by the Office of the Prime Minister of the Republic of Lithuania (March 01, 2010) //

http://www.Irs.It/pls/proj/dokpaieska.showdoc_l?p_id=22364\&p_org=18\&p_fix=n\&p_gov= (accessed May 31, 2011). 
contracts with top civil servants, the introduction of a rotation system (three-year tenure and possible rotation) and a special selection. It was planned to sign agreements with top civil servants concerning performance results. The content of these performance contracts is expressed only in general guidelines in the conception without foreseeing the factors of its application. This was the factor which caused a vigorously negatie reaction from politicians, heads of institutions, academics and trade unions. The Minister of the Interior reacted towards the criticism and sort of withdrew by responding critically in an interview. The conception project was also discussed in the Sunset Commission and received numerous remarks. ${ }^{45}$ Because of the remarks, revisions were introduced. After the revisions, the concept of performance agreement was introduced. The reform organizers defined a performance agreement as an agreement between a direct head and the employee, to be arranged and/or renewed annually, on the basis of performance results. It is important to note here that the concept of a top civil servant gets defined. Contracts were applied only for heads of departments. This reform document prolongs the tenure of top civil servants until 4 years and foresees its extension to 4 years. Also top civil servant rotation is defined in greater detail, as well as conditions of admission to work and procedures. In fact, this document created the higher civil service system.

Reform organizers managed to cope with the first obstacle, even though it was quite difficult. It was decided that the implementation of reforms will be performed by a working group created by the decree of the Prime Minister (Working Group of Coordination of Civil Service Improvement Conception) (henceforth, working group). ${ }^{46}$ Its main aim was to provide suggestions according to the conception of civil service improvement and to coordinate the preparation of legal acts. In fact, the working group had to prepare an extension project of the civil service law and substatutory acts, which indicate the implementation of different measures. As the interviews ${ }^{47}$ reveal, this working group was working by using the

${ }^{45}$ Nutarimas dèl valstybès tarnybos tobulinimo koncepcijos patvirtinimo (Resolution on the Authorization of the Civil Service Improvement Strategy Conception), Project by the Government of the Republic of Lithuania No. 10-2142-01 (May 31, 2010) //

http://www.Irs.It/pls/proj/dokpaieska.showdoc_l?p_id=37209\&p_query=\&p_tr2=\&p_org=\&p_fix=n\&p_g ov $=$ n (accessed September 14, 2011).

${ }^{46}$ Dèl darbo grupes sudarymo (On the Formation of a Legislative Working Group), Decree of the Prime Minister of the Republic of Lithuania No. 262 (July 13, 2010) //

http://www.min.litlex.It/scripts/sarasas2.dll?Tekstas=1\&Id=138981\&Zd=IR (accessed May 31, 2011).

47 In order to accomplish the proposed tasks, the method of qualitative data analysis, and semistructured interview, has been used. This research method has been chosen for the purpose of achieving greater consistency in addressing the problems at hand. Specific research questions have been formulated to specify and deepen each of the more general questions. In asking the questions provided below, attempts have been made to explore not only expressions of civil service reform initiatives, but also reasons for decisions and the contexts of that decision-making.

Essential criteria for the selection of experts involved work practices in preparing reform plans or analysing/assessing Lithuanian civil service system. It was decided that a semi-structured interview had to be conducted with officers of institutions, civil servants under central government. In total, 11 respondents took part in the qualitative research. On average individual interviews last for 1 hour. The 
specialists of the Ministry of the Interior (they prepared the final text of the draft law) and external experts. ${ }^{48}$ However, it was quite complicated to transfer the principles and model of system modernization to the instrumental level because of difficulties in defining the contents of contracts, deciding about tenure terms, etc. The working group received a number of remarks and suggestions from the interested institutions. ${ }^{49}$

In the reform document, the primary ideas about performance contracts were quite well developed. ${ }^{50}$ First, it was planned that the performance contracts would be of two types: 1) between top civil servants and civil servants (performance contracts) and 2) between top civil servants and political executives (performance agreements). From the point of view of contents, the former ones are defined in greater detail, as the position and payment for the service are estimated. The concept of an agreement expressed too strict obligations and did not describe the object, performance aims or results. Terms of performance agreements also remained undefined.

As concerns performance contracts for top civil servant rotation, the contents of these agreements and the monitoring of their creation are not completed. Project organizers expected that the contents of performance agreements will have to be defined by the Government. This norm demanded a more flexible regulation of the contractual relationship and a quicker reaction towards ineffective reform instruments. There are a number of unfinished issues related to contract making and the realization of rotation procedures. For example, the draft law did not contain the idea to establish the Commission of Civil Service Management, which would coordinate the selection of top civil servants, monitoring of performance evaluation, suggestions about payment for performance results and, possibly, monitoring of implemented contracts. As has already been mentioned, the establishment of such monitoring institutions would decrease the threats of politicization and favoritism, as well as ensuring the efficiency of the higher civil service system.

These unfinished issues impeded the preparation of reform documents because a number of critical remarks were provided by the members of the Sunset

interviews were anonymous. In this article names of respondents are not revealed, the language is not edited.

48 Interview with civil servant, Ministry of the Interior, March 12, 2011; Interview with director of department, Office of the Prime Minister, March 07, 2011.

49 Interview with director of department, Office of the Prime Minister, March 07, 2011; Interview with civil servant, Office of the Prime Minister, March 13, 2011.

50 Lietuvos Respublikos Valstybès tarnybos istatymo pakeitimo istatymo projektas (Draft Law on the Amendment of the Law on Civil Service of the Republic of Lithuania), No.10-4358-01 (October 27, 2010) // http://www.Irs.It/pls/proj/dokpaieska.showdoc_l?p_id=59292\&p_org=\&p_fix=y\&p_gov=n (accessed May 31, 2011). 
Commission and PMS. ${ }^{51}$ Consultants and coordinators of the reform suggested coming back to discussions about technical questions and taking consideration to the fact that imperfect law draft would receive criticism at Seimas. However, the reform did not stop. In the autumn of 2010, the way of its implementation changed. The Government decided that improvements have to be made with respect to the limits of its competencies rather than preparing a new law project as quickly as possible. Therefore, some Government resolutions were prepared, which transformed civil servants' assessment, employment and provision of classification class. The creation of an improved assessment system became a certain test for the planned contract system. ${ }^{52}$ This test was related to the definition of service performance results and the assessment of their implementation. This was a certain test-paper, which highlighted provisions towards one of the reform instruments. ${ }^{53}$ Practical difficulties in defining results also showed that the step towards performance contracts would not be an easy one.

At the beginning of 2011 , the working group proposed a new law project on civil service. It moved away from contract details; however, the idea to create a higher civil service was retained. It can be noted that the law project did not propose the conditions of fixed-term recruitment of a top civil servant (the law project proposed a 4 -year tenure and its possible extension for 4 years more). The extension of the tenure would be based on performance guidelines as the main document. Thus it speaks about a certain substitute for a contract. Nevertheless, the project makers suggested the regulation of arbitrary issues by Government resolutions. This law with small improvements was provided to the Seimas committees for discussion.

The point of view of the responsible Seimas committees was unambiguous and in many cases skeptical towards the project. ${ }^{54}$ Disapproval was not declared openly; however, it was clearly expressed through unofficial channels. Thus the preparation of reform documents was procrastinated for a long time. This obstacle made the reform organizers choose alternative ways of 'pushing' the reform

51 Minutes by the Sunset Commission under the Government of the Republic of Lithuania No. 63-23 (February 25, 2010) //

http://www.Irv.It/bylos/veikla/komisijos/saulelydzio/17_2010-11-25_posedzio_protokolas.pdf (accessed May 31, 2011).

52 Dél Lietuvos Respublikos Vyriausybès $2002 \mathrm{~m}$. birželio 17 d. nutarimo Nr. 909 'Dèl Valstybès tarnautoju kvalifikaciniu klasiu suteikimo ir valstybès tarnautoju tarnybinès veiklos vertinimo taisykliu bei Valstybès tarnautoju tarnybinès veiklos vertinimo kriteriju' pakeitimo (On the Amendment of the Resolution of the Government of the Republic of Lithuania of $17^{\text {th }}$ of June, 2002, No. 909 'On the Classification of Civil Servants and the Rules of the Evaluation of the Activity of Civil Servants and the Criteria of the Evaluation of the Activity of Civil Servants'), Resolution of the Government of the Republic of Lithuania No. 1860 (December 29, 2009) //

http://www3.Irs.It/pls/inter3/dokpaieska.showdoc_l?p_id=390283\%20 (accessed May 3, 2011).

${ }^{53}$ Interview with civil servant, Ministry of the Interior, May 06, 2011; Interview with civil servant, Office of the Prime Minister, March 13, 2011.

54 Interview with head of the institution, Office of the Prime Minister, June 20, 2011; Interview with director of department, Ministry of the Interior, June 06, 2011. 
documents. First, the interests about reform instruments began to be adjusted to significant Seimas committees more actively. For this, in the middle of May, 2011, an explanatory document was prepared 'Guidelines of Civil Service Improvement'. ${ }^{55}$ It discusses the objectives and implementation directions of state and statutory authority reform. This document of communicative type does not develop the issues indicated in the last reform document. It does not discuss contracts and recording of performance results; the discussion on assessment is also not developed.

\section{CIVIL SERVANTS' RESPONSE TO THE CIVIL SERVICE REFORM}

Most contemporary researchers, focusing on reforms, concentrate on the opinionated research of politicians as customers (principals) or the high administrative elite rather than civil servants as agents. ${ }^{56}$ Of course, it is not possible to maintain that the provisions of most system employees are not significant in the preparation or implementation of transformations. However, it is becoming a peripheral problem in the reform research.

This article is based on the main assumption that managerial reform instruments and the most important of them, performance contracts, influence negative attitudes as they limit career possibilities and decrease guarantees. Such transformations also critically influence civil servants' autonomy, behavior models and long-term satisfaction with their roles. Therefore, civil servants can take passive roles, opt out or become opportunists. ${ }^{57}$

A primary hypothesis was related to the fact that negative attitudes towards the reform depend on age and service time. Younger civil servants, who were employed a comparatively short time ago, oppose performance contracts less as the most radical means of reform. These attitudes are caused by personal experiences, lack of attachment to the system and persistent institutional cultures. However, the attitudes of the civil servants who worked for a longer time are negative because the implementation of contracts as the means of the reform is eventually threatening to their careers.

\section{DATA OF QUANTITATIVE RESEARCH AND METHODS}

This paper analyzes the attitudes of 400 civil servants; the data was collected by internet-telephone survey in 2011 . The survey sample (1000 civil servants) was

55 Valstybès tarnybos (iskaitant statutinę valstybès tarnybą) tobulinimo gairès (Working Document on the Improvement of Civil Service (Including the Statutory Civil Service)), Office of the Prime Minister of the Republic of Lithuania (May 20, 2011).

56 John Huber and Charles Shipan, supra note 2: 17-24.

57 Tom Christensen and Per Laergreid, "Administrative Reform Policy: The Challenges of Turning Symbols into Practice," Public Organization Review: A Global Journal 3 (2003): 3-27. 
created on the basis of the telephone book of civil servants, which can be found on Civil Service Department ${ }^{58}$ website; it includes 48444 civil servants. The research sample included all civil servants of various positions and duties. The response rate was 40 percent.

Table 1. Descriptive Statistics of the Main Survey Variables

\begin{tabular}{|l|c|c|c|c|c|}
\hline & N & Min. & Max. & Mean & St. Dev. \\
\hline $\begin{array}{l}\text { Support the current civil service (CS) } \\
\text { reform }\end{array}$ & 398 & 1 & 5 & 2,6 & 0,9 \\
\hline $\begin{array}{l}\text { Management improvement would be } \\
\text { significant for CS based on the model of } \\
\text { business sector }\end{array}$ & 396 & 1 & 5 & 3,3 & 1,2 \\
\hline $\begin{array}{l}\text { The rotation of top civil servants would be } \\
\text { significant for CS }\end{array}$ & 396 & 1 & 5 & 3 & 1,3 \\
\hline $\begin{array}{l}\text { Fixed-term contracts for top civil servants } \\
\text { would be significant for CS }\end{array}$ & 396 & 1 & 5 & 2,9 & 1,3 \\
\hline $\begin{array}{l}\text { Regulated evaluation of top civil servants' } \\
\text { performance would be significant for CS }\end{array}$ & 396 & 1 & 5 & 3,4 & 1,2 \\
\hline $\begin{array}{l}\text { Establishment of a higher civil service } \\
\text { would be significant for CS }\end{array}$ & 396 & 1 & 5 & 2,5 & 1,3 \\
\hline
\end{tabular}

The survey included questions related to attitudes towards the reform, contracts (as the most radical element of its content), and rotation. The attitudes towards the establishment of higher civil service and evaluation of top civil servants were also analyzed. In addition, the questionnaire included typical sociodemographic questions. Table 1 presents the descriptive statistics of the main variables.

\section{FINDINGS AND ANALYSIS}

The data of the survey shows (see Table 2) that the attitudes of civil servants towards the reform which is being prepared/implemented are relatively positive (positive attitudes comprise 13 per cent). However, one third of the respondents do not have a clear opinion about this reform. This is apparent comparing these results to the data of the survey carried out by Jan-Hinrik Meyer-Sahling and Vitalis Nakrošis in 2008. Three years ago, 45 percent supported the reform, ${ }^{59}$ while only 4 percent opposed the reform.

\footnotetext{
58 This institution administers the State Civil Servants' Register of the Republic of Lithuania.

59 Jan-Hinrik Meyer-Sahling and Vitalis Nakrošis, "Modernising the Lithuanian Civil Service", Report Paper (February 2009, Vilnius University, The University of Nottingham): 11.
} 
Table 2. View towards the Current Reform

\begin{tabular}{|l|c|c|}
\hline & Frequency & Percentage \\
\hline I strongly agree & 26 & 6,5 \\
\hline I partly agree & 190 & 47,7 \\
\hline I am indifferent & 131 & 32,9 \\
\hline I oppose & 38 & 9,5 \\
\hline I strongly oppose & 13 & 3,3 \\
\hline N & 398 & 100,0 \\
\hline
\end{tabular}

While analyzing the results, the question arose as to why the attitudes of civil servants changed so radically. Naturally, the political decisions made during the crisis, the implemented reforms (the decrease of civil servants' number) decreased the trust in government. In 2009 the trust in government decreased to 15 percent (in 2006 it reached 21 percent and in 2008 it reached 17 percent). ${ }^{60}$ This index reflected the attitudes of the society, which probably influenced the views of the civil servants. However, the consequences of the reforms of 2009-2010 (dismissals, lower work payment, insecurity about the position, higher work load, etc.) influenced the change in attitudes. This is also revealed by the survey of the Civil Service Department; its results reveal that civil servants' motivation decreased almost twice (compared to the years before the crisis) because of the decrease in financial payment, increased tension at work and pessimistic attitudes in the society regarding the current situation. ${ }^{61}$ The data of the qualitative research reveals that the negative attitudes were formed by the first reform instrument, i.e. evaluation of civil servants according to the results. ${ }^{62}$ Nevertheless, it seems that the significance of subjective experiences narrows the search for answers.

\section{EXPLANATIONS OF THE PARADOX OF CIVIL SERVANTS' ATTITUDES}

The results of the research regarding the attitude of civil servants towards the reform provide a puzzle, with several possible solutions. First, a different understanding about the aims of the reform conditioned the attitudes of the civil servants. For instance, their attitudes could be influenced by the popular (at least in academic discourse) idea of the current governing conception. However, the results

60 Standartinis Eurobarometras 72, Šalies ataskaita, Lietuva (Standard Eurobarometer Survey 72, Lithuania Report), ES Komunikacijos generalinis direktoratas (EU Directorate-General for Communication) (Autumn 2009) //

http://ec.europa.eu/public_opinion/archives/eb/eb72/eb72_It_It_nat.pdf p.31 (accessed May 3, 2011).

61 Valstybès tarnautoju motyvavimo galimybiu sunkmečio laikotarpiu tyrimo rezultatai (Results of the Study of the Motivational Patterns of Civil Servants in the Time of Hardship), Lietuvos Respublikos Valstybès tarnybos departamentas (Civil Service Department of the Republic of Lithuania) (September 29, 2009) // http://www.vtd.It/index.php?784584118_(accessed May 3, 2011).

62 Interview with civil servant, Ministry of the Interior, May 05, 2011; Interview with civil servant, Ministry of the Interior, May 06, 2011; Interview with civil servant, Office of the Prime Minister, March 13, 2011. 
of the survey show that this assumption is not true. When the civil servants were asked if 'The civil service has to be reformed because it has lost contact with the society and does not fulfil its needs', they provided almost the same answers as to the question about the current reforms (these variables show a positive correlation, Spearman $=0.373, \mathrm{P}<0.001)$. Taken relatively, one can note that 7.2 percent respondents more were supportive of the reforms oriented towards participatory governing. However, the differences between negative attitudes were not so significant.

Another explanation can be related to the fact that civil servants are dissatisfied with the civil service system and view the proposed reform or at least its aims and some elements relatively positively. As noted by a participant of the survey, 'The aims of the reform are nice and acceptable, only devil sometimes hides in the details.' For this, the correlation between the evaluation of the reform and managerial variables (performance contracts, rotation, performance evaluation and establishment of higher civil service) were evaluated. Statistical correlation between these variables was not identified. Even though the attitudes towards the current reform and higher civil service establishment were confirmed, the correlation is not very strong (Kendal tau- $\mathrm{b}=-0.242, \mathrm{P}<0.001$ ). Naturally, the establishment of higher civil service was viewed negatively by 51.3 percent of the respondents. Thus the establishment of an egalitarian body was viewed as a possibly insignificant element by a part of the respondents. However, other elements of the higher civil servant system were viewed more positively (see Table 3 ).

Table 3. Attitudes towards the element of Civil Servant System Development (percentage)

\begin{tabular}{|l|c|c|c|c|}
\hline & Favourable & Neutral & Opposing & In total \\
\hline $\begin{array}{l}\text { Improvement of leadership based } \\
\text { on the business sector model }\end{array}$ & 49,7 & 27,3 & 23 & 100,0 \\
\hline Top civil servant rotation & 39,6 & 24 & 36,4 & 100,0 \\
\hline $\begin{array}{l}\text { Application of fixed-term contracts } \\
\text { for top civil servants }\end{array}$ & 34,1 & 24,5 & 41,4 & 100,0 \\
\hline $\begin{array}{l}\text { Specially regulated evaluation of } \\
\text { top civil servants' performance }\end{array}$ & 50,8 & 28,3 & 21 & 100,0 \\
\hline $\begin{array}{l}\text { Establishment of higher civil } \\
\text { service }\end{array}$ & 22,2 & 26,5 & 51,3 & 100,0 \\
\hline
\end{tabular}

The respondents viewed adaptation of business sector models exceptionally favorably (see Table 3 ). This was conditioned by the vague term(s) ("business sector model") used in the questionnaire. This paper attempts to clarify normative attitudes towards business principles, philosophy and also adaptation of vague improvement measures. The obtained data shows a certain popularity of New Public Management in the thinking of public servants. Possible orientations are confirmed by the research carried out by Eglè Butkevičienė, Eglè Vaidelytè and Giedrius 
Žvaliauskas, which was based on the survey (2008). It indicated that the most important ideas are related to achievements, universality and self-assurance. ${ }^{63}$ This is also confirmed by the research on civil servants' motivation performed by Jolanta Palidauskaitè; here too big bureaucratism is understood as a demotivating factor. ${ }^{64}$ It should also be noted that the respondents from municipalities viewed the application of managerial methods slightly more favorably than those working in the ministries and subordinate institutions. Attitudes of the respondents were determined not only by a normative aspect; a number of them viewed the means of managerial reform favorably as well. For example, the respondents viewed the evaluation of top civil servants' performance positively. ${ }^{65}$

Fixed-term contracts and top civil servants rotations were also viewed relatively favorably (see Table 3 ). One can note that rotation and contracts were viewed as a unified element (Kendall tau_b $=0.619, P<0.001$ ) without any major differences. These attitudes could have been determined by dysfunctions of top civil servants as elements of the system: big number of leading staff, politicization, communication problems, decreasing responsibility in decision-making, etc. ${ }^{66}$ However, it should be taken into consideration that most respondents were specialists according to their position (86 percent in total).

The obtained results show that the respondents of the survey view managerial reforms quite positively. Thus the primary hypothesis about possible clearly negative attitudes was not confirmed. One may ask what motives determined these opinions. It seems that they could have been determined by contextual factors. For instance, this could have been indirectly influenced by a significant decrease of trust in state and municipality institutions. In 2006, 48 percent of Lithuanian residents trusted in institutions, while in 2009 and 2010 the number decreased to

63 Eglè Butkevičienè, Eglè Vaidelytė, and Giedrius Žvaliauskas, "Lyderystės raiška Lietuvos valstybès tarnyboje" (Roles of Leadership in Lithuanian Public Sector), Viešoji politika ir administravimas 27 (2009): 40.

64 Jolanta Palidauskaitè and Irena Segalovičienè, "Valstybès tarnautoju motyvacijos profilis Lietuvoje: empirinio tyrimo rezultatu analizè" (The Motivational Profile of Lithuanian Civil Servants: Analysis of the Results of Empirical Research), Organizaciju vadyba, sisteminiai tyrimai 80 (2008): 80-87.

65 This evaluation was viewed as twice more favorable than the annual evaluation, which was improved at the end of 2009, as the formulation of performance objectives and the evaluation of their achievement were introduced. Only 27.5 per cent of respondents answered positively to the question whether the annual formulation of performance objectives and evaluation of their achievement would improve performance quality. However, usefulness of responsibility and introduction of activity aims were viewed more positively. 36.9 per cent of respondents noted that this means will be useful in introducing more responsibility. A similar percentage of the respondents answered about the introduction of clearer activity aims. Why is this comparison important? Annual evaluations of a civil servant were the test-paper, which shows the attitudes towards a worked-out means, which seems to be useful only for a part of respondents. These points of view are based on personal experience, while attitudes about the significance of top civil servants' evaluation are an imaginary means in the improvement of the system.

66 Valstybinio audito ataskaita: statutines vidaus tarnybos valdymas (Report of the State Audit: Management of Statutory Civil Service), Report of the National Audit Office of Lithuania No. VA-P-40-3-2 (January 13, 2011) // www.vkontrole.It/failas.aspx?id=2301 (accessed May 3, 2011); Jan-Hinrik MeyerSahling and Vitalis Nakrošis, supra note 59: 18-20. 
46 percent. ${ }^{67}$ The current research on reforms shows that decreasing trust in civil service and reforms becomes a pressure technique, which causes anxiety and makes people look for a way out. ${ }^{68}$ Negative attitudes on the part of the residents encourage the civil servants to look for solutions, think about changes and possible transformations. Managerial ideas here become practically the only choice, as there are no alternatives, while the New Public Management doctrine has dominated in the discourse of Lithuanian practitioner discourses for approximately a decade. Timothy Besley has noted that bureaucrats have a certain understanding about their mission; ${ }^{69}$ thus they can value reforms according to their positive or negative influence on their prior understanding.

These explanations provide alternatives for interpretation; however, the puzzle still lacks several details. While analyzing deeper the civil servants' attitudes, it is necessary to come back to the hypothesis that was raised earlier. The attitudes towards contracts (a dependent variable) are conditioned by age and duration of service (independent variables). The analysis of survey results shows that there is no direct correlation between age groups and attitude towards contracts (see Table 4). The correlations, which are not very strong, can be indicated among the attitudes of different age groups towards rotation and leadership improvement based on the models of business sector.

Table 4. Attitudes towards Contracts and other Managerial Means (Kendall tau_b)

\begin{tabular}{|l|c|c|}
\hline & Age & Length of service \\
\hline Leadership improvement based on business sector models &,$- 154^{* *}$ &,$- 203^{* *}$ \\
\hline Top civil servants rotation &,$- 109^{* *}$ &,$- 121^{* *}$ \\
\hline Fixed-term contracts for top civil servants &,- 062 &,$- 122^{* *}$ \\
\hline Establishment of a higher civil service &,- 019 &,$- 150^{* *}$ \\
\hline N.396, **. Correlation is significant at the 0.01 level (2-tailed). \\
\hline
\end{tabular}

There is a correlation between the variables of service length and attitudes towards performance contracts. However, this statistical correlation is not very strong. While trying to clarify the attitudes, which preconditioned the factors, one can note that the respondents who have worked a comparatively short time in the civil service (up to 10 years), view the means of the reform more favorably than those who have worked in the system for a long time (eleven or more years).

\footnotetext{
67 Lietuvos gyventoju apklausos apie pasitikejjimą valstybès ir savivaldybiu institucijomis ir istaigomis $2006-2010$ m. (Survey Researches on the Lithuanian Citizens' Trust in State and Municipal Institutions and Agencies, 2006-2010), Lietuvos Respublikos Vidaus reikalu ministerija (Ministry of the Interior of the Republic of Lithuania) // http://www.vakokybe.It/index.php?id=307 (accessed October 3, 2011).

${ }^{68}$ Christopher Pollitt and Geert Bouckaert, supra note 1: 146.

69 Timothy Besley, Principled Agents? The Political Economy of Good Government (Oxford: Oxford University Press, 2007), p. 115.
} 
Table 5. Attitudes of Civil Servants towards the Use of Contracts

\begin{tabular}{|c|c|c|c|c|c|c|}
\hline & \multicolumn{6}{|c|}{ Length of service } \\
\hline & to 5 years & -10 years & $11-15$ years & $16-20$ years & $\begin{array}{l}\text { more than } \\
20 \text { years }\end{array}$ & In total \\
\hline \multirow{2}{*}{$\begin{array}{l}\text { Absolutely } \\
\text { insignificant }\end{array}$} & 13 & 12 & 15 & 17 & 22 & 79 \\
\hline & $16,5 \%$ & $15,2 \%$ & $19,0 \%$ & $21,5 \%$ & $27,8 \%$ & $100,0 \%$ \\
\hline \multirow{2}{*}{$\begin{array}{l}\text { More significant } \\
\text { rather than } \\
\text { insignificant }\end{array}$} & 12 & 23 & 25 & 11 & 14 & 85 \\
\hline & $14,1 \%$ & $27,1 \%$ & $29,4 \%$ & $12,9 \%$ & $16,5 \%$ & $100,0 \%$ \\
\hline \multirow{2}{*}{$\begin{array}{l}\text { Neither significant, } \\
\text { nor insignificant }\end{array}$} & 26 & 18 & 18 & 15 & 20 & 97 \\
\hline & $26,8 \%$ & $18,6 \%$ & $18,6 \%$ & $15,5 \%$ & $20,6 \%$ & $100,0 \%$ \\
\hline \multirow{2}{*}{$\begin{array}{l}\text { More significant } \\
\text { rather than } \\
\text { insignificant }\end{array}$} & 20 & 28 & 19 & 7 & 7 & 81 \\
\hline & $24,7 \%$ & $34,6 \%$ & $23,5 \%$ & $8,6 \%$ & $8,6 \%$ & $100,0 \%$ \\
\hline \multirow[t]{2}{*}{ Very significant } & 15 & 11 & 7 & 7 & 14 & 54 \\
\hline & $27,8 \%$ & $20,4 \%$ & $13,0 \%$ & $13,0 \%$ & $25,9 \%$ & $100,0 \%$ \\
\hline
\end{tabular}

These different attitudes can be explained by several issues. First, it can appear for the civil servants who worked longer that the use of contracts can potentially limit their career possibilities and employment in the higher civil service which is being created. This idea is confirmed by the fact that the attitudes towards contracts, top civil servants rotation and establishment of the higher civil service almost coincide (see Table 1 and Table 4). Second, the civil servants who worked shorter can expect that the use of contracts and other managerial means can accelerate their advance in the system.

The indicated correlations show that the attitudes of civil servants towards performance contracts were preconditioned not only by views towards the elements of reform content and possible opposition towards unfavorable reforms, but also by the length of service in the system and dependence on it. However, the solution to this puzzle and the analysis of the phenomenon still lack the last element. Actually, the deep reasons determining the attitudes of civil servants remain unclear. Nevertheless, an attempt can be made to reconstruct them on the basis of qualitative research data.

\section{7. "A GOOD IDEA, BUT THE DEVIL HIDES IN THE DETAILS"}

The analysis of individual interview data reveals that the attitudes of civil servants and top civil servants towards the phenomenon are not shared in common. A part of the respondents supported contracts, rotation and the establishment of higher civil service, making concessions about certain details. Another part of the respondents doubted about the acceptability of radical reform elements, their necessity, perfection and possible obstacles of implementation. 
However, the respondents who were critical about the content elements of this reform mostly made concessions with regard to the higher civil service system. First, they explained that contracts do not match the criteria of the recently created system. Another argument was possible politicization of the reform means; they explained that contracts contradict to the existing norms of public law and talked about the difficulties of practical application. One respondent provided the arguments the following:

... Contracts? Possibly. It depends on the culture [...] Contracts with top civil servants would be quite efficient if the results were recorded in a clear and professional way [...]. On the other hand, I notice that contract service is applied in the countries where the labour market is broad. This is especially suitable for project management because when one project ends, you go elsewhere. Big countries provide many choices but in Lithuania, when you are a specialist in a certain area, you have to go deep into the area, and the possibilities are quite limited [...]. Thus balance has to be kept; even though there might be difficulties, the civil service has to be stable because a person sacrifices for the civil service during a certain period. When there are hard times, the state has to deal with some important things. ${ }^{70}$

The analysis of this interview reveals an ambiguous attitude, which is symptomatic of this research. First, the respondent indicates that the means can be acceptable. Then he moves on to reserved arguments explaining the possible consequences of successful adaptation. Efficiency of contract use is related to culture, top civil servants mobility in the labor market, and content of contracts and time of the reform. It can be noted that he, as the head of a territorial subdivision of the agency, understands contracts in civil service in his own way (the data of the interview show that he was acquainted with the contents of the reform). He relates this means only to specialization of activity (he is for head specialists rather than generalists) and possibility of very clearly defined results.

This is a very important element. However, Western civil service systems define aims of performance agreements in a flexible way, taking into consideration the specificity of the head's service. In general, attention to details shows that the respondents were very cautious about implementation efficiency. As one interviewee responded, "it is a good idea, but devil hides in the details. ${ }^{171}$

According to the lawyers who work in ministries, these details are expressed on the valid legal basis. Their observations, such as "What can you agree about?

\footnotetext{
70 Interview with head of the institution, Customs Department under the Ministry of Finance, May 05, 2011.

${ }^{71}$ Interview with top civil servant, Chief Official Ethics Commission, May 12, 2011.
} 
Everything is indicated in the law $[\ldots]^{\prime 72}$ or "Practically everything is defined in legal acts. There is nothing to agree about in the performance contracts"73, sort of indicated that this means of the reform is redundant and its use can eventually lead to a failure. It should be noted that the aforementioned respondents directly contributed to the preparation of reform documents. Their negative attitudes are expressed in some interviews:

Thus the first one (the first project) included performance contracts, after that we mumbled all the time that this agreement does not have any sense as everything is indicated in the law. Because there is nothing to agree about. You mean it is necessary to rewrite the law? Then there is bureaucracy. But if we talk about agreement on tasks, not on the performance contract, then let it be. I don't think that they impede something. ${ }^{74}$

However, this opinion shows that the respondents-lawyers viewed negatively the ideas to use strictly regulated agreements, while they did not object to performance agreements. From this perspective, these are quite rational recommendations, which can prevent lawyers from unsuccessful reforms. One can note that these suggestions corrected the implementation of the reform fundamentally. A number of reform organizers noted that during the process of its preparation, there was a 'struggle' with the lawyers about the reform contents. There are remarks 'about hindrance to reforms' ("In the ministries the lawyers should help to implement reforms, while all of them are disturbing"75) and conflicts while preparing reform documents ("There are always problems with lawyers. Because lawyers work for the state and the state for lawyers" ${ }^{\prime 76}$ ). It seems that more radical suggestions about the system transformation have become the epicenter of interests and ideas. This is also confirmed by one of the main organizer's idea that "There were groups of ministry departments walking, and there were not only one which persistently suggested stopping or changing the reform. ${ }^{\prime 77}$

Thus the opposition of the administrative elite will be apparent. Most often, it is noted that there are protests against reform means directed towards top civil servants. One can ask whether the opposing ones were only administrative elite and if they were, then how and why. The answer may be easily found in the interview material. It shows that a significant part of lower level ministry civil

\footnotetext{
${ }_{73}^{7}$ Interview with civil servant, Ministry of the Interior, April 04, 2011.

${ }^{73}$ Interview with director of department, Ministry of the Interior, May 12, 2011.

${ }^{74}$ Interview with civil servant, Ministry of the Interior, April 04, 2011.

75 Interview with director of department, Ministry of the Interior, June 06, 2011.

${ }^{76}$ Interview with director of department, Office of the Prime Minister, March 07, 2011.

77 Interview with head of the institution, Office of the Prime Minister, June 20, 2011.
} 
servants reacted sensitively towards the first reform documents. According to one of them:

The reform has to be carried out after considering it better. Why was rotation introduced? Nobody understood that. I can be moved somewhere to Skuodas, but my family is here, the home is bought for loans. [...] When everybody found out, they chuckled, but after that got seriously scared [...] Total opposition rippled, and not only among civil servants. The people communicate, the people know the necessary officials. Somebody has acquaintances in Seimas, others in the Presidential Palace and could influence decisions respectively. ${ }^{78}$

This situation shows that the appearance of the first reform documents was followed by emotions. Further reaction was the attempt to create influence using personal contacts. Suggestions on rotations received the most sensitive reaction, while the aspect of contracts with top civil servants affected the civil servants less. One may question if there was a lack of information explaining reform ideas. According to Maeder, it is necessary to prove the purposefulness of the reform in order for the bureaucrats not to oppose it. ${ }^{79}$ The interview data show that around 70 events (meetings, discussions, etc.) were organized. ${ }^{80}$ The press was writing sufficiently enough about the reforms. However, it seems that it was not enough in order to decrease opposition.

However, it seems that the fuss made by the civil servants cannot be viewed as a critical obstacle. The analysis of the interviews reveals that the opposition was faced in responsible committees of the parliament. Different politicians, who had been creating former reform, were opposing especially actively (including the leading parties). ${ }^{81}$ In addition, the socio-economic environment was also changing in 2010. To be precise, saving was not the force influencing the civil service reform. Finally, the analysis of the survey shows that civil servants were not opposing reforms absolutely harshly. The attitudes of civil servants and the opposition of part of them was not 'the biggest devilish detail.'

\section{CONCLUSIONS}

The analysis of theories, facts and opinions allowed the formation of a puzzle, the picture of which shows that performance contracts with top civil servants as a means of the civil service reform received ambiguous evaluations. The ideas to

\footnotetext{
78 Interview with civil servant, Ministry of the Interior, May 05, 2011.

79 Christoph Maeder, "The Poetics of Management, and the Politics of Organizational Cultures. A Sociological view on NPM - Reform in Switzerland": 73; in: Kuno Schedler and Isabella Proeller, eds., Cultural Aspects of Public Management Reform (Bingley: Emerald Group Publishing Limited, 2007).

${ }^{80}$ Interview with civil servant, Office of the Prime Minister, March 13, 2011

81 Interview with head of the institution, Office of the Prime Minister, June 20, 2011; Interview with director of department, Office of the Prime Minister, March 07, 2011.
} 
create contractual relationships and rotations in Lithuanian civil service (the level of top level civil servants) inhibited the preparation of reform documents, caused stress and confusion. Thus the initiators of radical reform means had to refuse ideas in creating contract relationship with the senior civil servants.

As the data of the qualitative research reveals, the establishment of contractual relationships determined the civil servants' opposition to the matter(s). Its expression (criticism in the press and public discussion, direct and indirect pressing from the organizers of the reform) was apparent. Notable pressure arose from the administrative elite of the ministries and some actors, e.g. the lawyers. This leads to the conclusion that the reformers did not have significant support from the administrative elite of the ministries. In the studies of reform preparation and implementation, this factor is viewed as critical in the implementation of transformations.

However, there is a paradox: the majority of civil servants do not express negative opinions on contracts and the implementation of other managerial reforms. In general, a significant number of the civil servants view the reform positively, as the survey data reveals. They also show that the attitudes are determined by the time of service in the system. The civil servants who work in the system for a short time view the introduction of contract relationship positively. However, the hypothesis that this is determined by age and the attitudes related to it was not confirmed. Such results of the survey are paradoxical. It seems that they could have been determined by other factors: the objective to change based on the increasing mistrust in the civil service, the decreased pressure of the economical crisis since 2011 and non-understanding that there are alternatives to managerial reforms.

\section{BIBLIOGRAPHY}

1. "Administrative Capacity in the New EU Member States: the Limits of Innovation?" Document of the World Bank (December 2006) // http://siteresources.worldbank.org/INTECA/Resources/EU8_AdminCapacity_D ec06.pdf (accessed December 01, 2011).

2. Ban, Carolyn. "The Changing Role of the Human Resource Office": 41-57. In: Stephen E. Condrey, ed. Handbook of Human Resource Management in Government. San Francisco: Jossey Bass, 2005.

3. Besley, Timothy. Principled Agents? The Political Economy of Good Government. Oxford: Oxford University Press, 2007. 
4. Binderkrantz, Anne, and Jorgen Christensen. "Governing Danish Agencies by Contract: From Negotiated Freedom to the Shadow of Hierarchy." Journal of Public Policy 29 (2009): 55-78.

5. Brans, Marleen, and Annie Hondeghem. "The Senior Civil Service in Belgium": 121-147. In: Edward C. Page and Vincent Wright, eds. Bureaucratic Elites in Western European States. A Comparative Analysis of Top Officials. Oxford: Oxford University Press, 2002.

6. Butkevičienè, Eglè, Eglè Vaidelytè, and Giedrius Žvaliauskas. "Lyderystès raiška Lietuvos valstybès tarnyboje" (Roles of Leadership in Lithuanian Public Sector). Viešoji politika ir administravimas 27 (2009): 36-44.

7. Christensen, Jorgen. "Danish Public Management Reform before and after NPM": 279-299. In: Shaun Goldfinch and Joe L. Wallis, eds. International Handbook of Public Management Reform. Cheltenham: Edward Elgar Publishing, 2009.

8. Christensen, Tom, and Per Laergreid. "Administrative Reform Policy: The Challenges of Turning Symbols into Practice." Public Organization Review: A Global Journal 3 (2003): 8.

9. Cole, Alistair, and Jones Glyn. "Reshaping the State: Administrative Reform and New Public Management in France." Governance 18 (2005): 567-588.

10. Corte-Real, Isabel. "Public Management Reform in Portugal: Successes and Failures." International Journal of Public Sector Management 21 (2008): 205229.

11. Cristofoli, Daniela, Greta Nasi, Alex Turrini, and Giovanni Valotti. "Civil Service Reforms in Italy: The Importance of External Endorsement and Administrative Leadership." Governance 24 (2) (2011): 261-283.

12. Dierickx, Guido. "Senior Civil Servants and Bureaucratic Change in Belgium." Governance 16 (2003): 321-348.

13. Durant, Robert F., and Jerome S. Legge. "Politics, Public Opinion and Privatization in France: Assessing the Calculus of Consent for Market Reforms." Public Administration Review 62 (3) (2002): 307-321.

14. Gains, Francesca, Peter John, and Gerry Stoker. "When Do Bureaucrats Prefer Strong Political Principals? Institutional Reform and Bureaucratic Preferences in English Local Government." British Journal of Politics and International Relations 10(4) (2008): 649-655.

15. Gregory, Robert, and Jorgen Christensen. "Similar Ends, Differing Means: Contractualism and Civil Service Reform in Denmark and New Zealand." Governance 17 (2004): 59-82. 
16. Gualmini, Elissabeta. "Restructuring Weberian Bureaucracy: Comparing Managerial Reforms in Europe and the United States." Public Administration 86 (1) (2008): 75-94.

17. Halligan, John. "Anglo-American Systems: Easy Diffusion": 50-65. In: Jos C.N. Raadschelders, Theo Toonen, and Frits M. Van der Meer, eds. The Civil Service in the 21st Century: Comparative Perspectives. Basingstoke: Palgrave Macmillan, 2007.

18. Halligan, John. "The Australian Public Service: Redefining Boundaries, Administrative Traditions and the Anglo-American Democracies": 70-113. In: John Halligan, ed. Civil Service Systems in Anglo-American Countries. Cheltenham: Edward Elgar, 2003.

19. Hood, Christopher, and Martin Lodge. The Politics of Public Service Bargains: Reward, Competency, Loyalty - and Blame. Oxford: Oxford University Press, 2006.

20. Hood, Christopher. "Individualized Contracts for Top Public Servants: Copying Business, Path-Dependent Political Re-Engineering-or Trobriand Cricket?" Governance 11 (1998): 443-462.

21. Howlett, Michael. "Administrative Styles and the Limits of Administrative Reform: A Neo-Institutional Analysis of Administrative Culture." Canadian Public Administration 46 (2003): 471-494.

22. Huber, John, and Charles Shipan. Deliberate Discretion? The Institutional Foundations of Bureaucratic Autonomy. Cambridge: Cambridge University Press, 2002.

23. Ketelaar, Anne, Nick Manning, and Edouard Turkisch. "Performance-Based Arrangements for Senior Civil Servants OECD and other Country Experiences." OECD Working Papers on Public Governance Vol. 5 (2007) // DOI: 10.1787/16072663075 28.

24. Lægreid, Per. "Top Civil Servants under Contract. Public Administration." Public Administration 4 (2000): 879-896.

25. Lietuvos gyventoju apklausos apie pasitikejjimą valstybejs ir savivaldybiu institucijomis ir istaigomis $2006-2010 \mathrm{~m}$. (Survey Researches on the Lithuanian Citizens' Trust in State and Municipal Institutions and Agencies, 2006-2010). Lietuvos Respublikos Vidaus reikalu ministerija (Ministry of the Interior of the Republic of Lithuania) // http://www.vakokybe.It/index.php?id=307 (accessed October 3, 2011).

26. LK (TS) Seimo rinkimu programa 2008-2012 (2008 - 2012 Election Program of "Homeland Union - Lithuanian Christian Democrats" Party) // 
http://www.tsajunga.It/index.php/seimo_rinkimu_programa_2008_2012/908 1 (accessed November 1, 2011).

27. Maeder, Christoph. "The Poetics of Management, and the Politics of Organizational Cultures. A Sociological view on NPM - Reform in Switzerland": 65-75. In: Kuno Schedler and Isabella Proeller, eds. Cultural Aspects of Public Management Reform. Bingley: Emerald Group Publishing Limited, 2007.

28. Maniokas, Klaudijus. "Valstybès tarnybos reforma ar jos chunveibiniškas griovimas?" (Civil Service Reform or Its Demolition in Hongweibing Style). Delfi.lt (June 1, 2009) // http://www.delfi.It/news/ringas/lit/article.php?id=22428924 (accessed October 1, 2011).

29. Mascarenhas, R.C. "The New Zealand Public Service: National Identity and International Reform": 113-147. In: Jos C.N. Raadschelders, Theo Toonen, and Frits M. Van der Meer, eds. The Civil Service in the $21^{\text {st }}$ Century: Comparative Perspectives. Basingstoke: Palgrave Macmillan, 2007.

30. Masiulis, Kęstutis. "Saulèlydžio komisijai jau artèja saulèlydis" (Sunset Commission Comes to Its Sunset). Lrytas.It (August 8, 2009) [Interview with Ex-Member of Sunset Commission Kęstutis Masiulis] // http://www.Irytas.It/-12498786351247812444-saul\%C4\%97lyd\%C5\%BEiokomisijai-jau-art\%C4\%97ja-saul\%C4\%97lydis.htm (accessed October 1, 2011).

31. Meyer-Sahling, Jan-Hinrik, and Vitalis Nakrošis. "Modernising the Lithuanian Civil Service". Report Paper (February 2009; Vilnius University, the University of Nottingham): 1-185.

32. Meyer-Sahling, Jan-Hinrik. Post-Accession Sustainability of Civil Service Reform in Central and Eastern Europe. Paris: OECD-SIGMA Publications, 2009.

33. Nakrošis, Vitalis. "Viešojo valdymo reformos Lietuvoje: kodèl ir kuo reikia pakeisti Naujaja viešaja vadyba" (Reforms of Public Administration in Lithuania: Why and by whom the New Public Management Has to Be Replaced). Politologija 1 (2011): 65-98.

34. Ongaro, Edoardo. Public Management Reform and Modernization, Trajectories of Administrative Change in Italy, France, Greece, Portugal and Spain. Cheltenham \& Northampton: Edward Elgar, 2009.

35. Palaitis, Raimundas. "Reikia ne valdyti, o tarnauti" (It Is Necessary to Serve, not to Govern). Delfi.lt (September 14, 2009) [Personal interview about implementation of civil service reform] // 
http://www.delfi.lt/news/daily/lithuania/rpalaitis-reikia-ne-valdyti-otarnauti.d?id=24031168 (accessed October 1, 2011).

36. Palidauskaitè, Jolanta, and Irena Segalovičienè. "Valstybès tarnautoju motyvacijos profilis Lietuvoje: empirinio tyrimo rezultatu analizè" (The Motivational Profile of Lithuanian Civil Servants: Analysis of the Results of Empirical Research). Organizaciju vadyba, sisteminiai tyrimai 80 (2008): 7390.

37. Parrado, Salvador. "Failed Policies but Institutional Innovation through 'Layering' and 'Diffusion' in Spanish Central Administration." International Journal of Public Sector Management 21 (2008): 230-252.

38. Pedersen, Peter, Hanne Sorensen, and Jakob Vestergaard. "Public Service Performance Contracting in Denmark." OECD (1999) // http://www.oecd.org/dataoecd/10/62/1902729.pdf (accessed May 10, 2011).

39. Peters, Guy B. "Administrative Traditions and the Anglo-American Democracies": 10-27. In: John Halligan, ed. Civil Service Systems in AngloAmerican Countries. Cheltenham: Edward Elgar, 2003.

40. Peters, Guy B. "What Works? The Antiphons of Administrative Reforms": 78108. In: B. Guy Peters and Donald Savoie, eds. Taking Stock: Assessing Public Sector Reform. Montreal and Kingston: Canadian Centre for Management Development and McGill-Queen's University Press, 1998.

41. Peters, Guy B., and Martin Painter. "Conclusion: Administrative Traditions in an Era of Administrative Change": 234-237. In: B. Guy Peters and Martin Painter, eds. Tradition and Public Administration. New York \& Houndmills: Palgrave Macmillan, 2010.

42. Pivoras, Saulius. "Post-Soviet Transformation of Bureaucracy in Lithuania: Main Features and Trends." Baltic Journal of Law \& Politics 1 (2008): 111-131 // DOI: 10.2478/v10076-008-0007-z.

43. Pollitt, Christopher, and Geert Bouckaert. Public Management Reform: A Comparative Analysis-New Public Management, Governance, and the NeoWeberian State. Oxford: Oxford University Press, 2011.

44. Putseys, Line, and Annie Hondeghem. "Contractualisation of Top Civil Servants: an International Comparative Research." Annual Meeting of the European Group of Public Administration (EGPA) (September 2003) // http://soc.kuleuven.be/io/pubpdf/IO06060003.pdf (accessed October 11, 2011).

45. Pyper, Robert, and June Burnham. "The British Civil Service: Perspectives on 'Decline' and 'Modernisation'." The British Journal of Politics \& International Relations 13 (2011): 189-205. 
46. Rouban, Luc. "Reform without doctrine: public management in France." International Journal of Public Sector Management 21 (2008): 133-149.

47. Schick, Allen. "The Spirit of Reform: Managing the New Zealand State Sector in a Time of Change." A Report Prepared for the State Services Commission and the Treasury, New Zealand (August 1996) // http://www.thedplg.gov.za/subwebsites/igr/docs/Publications/Pub5.pdf (accessed November 11, 2008).

48. Spanou, Calliope. "State Reform in Greece: Responding to Old and New Challenges." International Journal of Public Sector Management 21 (2008): 150-173.

49. Standartinis Eurobarometras 72, Šalies ataskaita, Lietuva (Standard Eurobarometer Survey 72, Lithuania Report). ES Komunikacijos generalinis direktoratas (EU Directorate-General for Communication) (Autumn 2009) // http://ec.europa.eu/public_opinion/archives/eb/eb72/eb72_It_It_nat.pdf p.31 (accessed May 3, 2011).

50. Steen, Trui, and Frits M. Van der Meer. "Dutch Civil Service Leadership: Torn between Managerial and Policy-Oriented Leadership Roles": 109-126. In: Jeffrey A. Raffel, Peter Leisink, and Anthony Middlebrooks, eds. Public Sector Leadership: International Challenges and Perspectives. Cheltenham: Edward Elgar, 2009.

51. Valstybès tarnautoju motyvavimo galimybiu sunkmečio laikotarpiu tyrimo rezultatai (Results of the Study of the Motivational Patterns of Civil Servants in the Time of Hardship). Lietuvos Respublikos Valstybès tarnybos departamentas (Civil Service Department of the Republic of Lithuania) (September 29, 2009) // http://www.vtd.It/index.php?784584118_(accessed May 3, 2011).

52. Van Dorpe, Karolien, Annie Hondeghem, Montuelle Caroline, and Christian de Visscher. "Assessing the Belgian Mandate System from an International Comparative Perspective." ESPA Conference, Rotterdam (September 3-6, 2009) //

http://soc.kuleuven.be/io/egpa/HRM/rotterdam/Van\%20Dorpe-HondeghemMontuelle\&De\%20Visscher2008.pdf (accessed May 23, 2011).

\section{LEGAL REFERENCES}

1. Dèl darbo grupés sudarymo (On the Formation of a Legislative Working Group). Decree of the Prime Minister of the Republic of Lithuania No. 262 (July 13, 2010) // 
http://www.min.litlex.It/scripts/sarasas2.dll?Tekstas $=1 \& I d=138981 \& Z d=I R$ (accessed May 31, 2011).

2. Dèl Lietuvos Respublikos Vyriausybès 2002 m. birželio 17 d. nutarimo Nr. 909 'Dèl Valstybès tarnautoju kvalifikaciniu klasiu suteikimo ir valstybès tarnautoju tarnybinès veiklos vertinimo taisykliu bei Valstybès tarnautoju tarnybinès veiklos vertinimo kriteriju' pakeitimo (On the Amendment of the Resolution of the Government of the Republic of Lithuania of $17^{\text {th }}$ of June, 2002, No. 909 'On the Classification of Civil Servants and the Rules of the Evaluation of the Activity of Civil Servants and the Criteria of the Evaluation of the Activity of Civil Servants'). Resolution of the Government of the Republic of Lithuania No. 1860 (December 29, 2009) // http://www3.Irs.It/pls/inter3/dokpaieska.showdoc_l?p_id=390283\%20 (accessed May 31, 2011).

3. Lietuvos Respublikos Valstybès tarnybos istatymo pakeitimo istatymo projektas (Draft Law on the Amendment of the Law on Civil Service of the Republic of Lithuania). No. 10-4358-01 (October 27, 2010) // http://www.Irs.It/pls/proj/dokpaieska.showdoc_l?p_id=59292\&p_org=\&p_fix= y\&p_gov=n (accessed May 31, 2011).

4. Minutes by the Sunset Commission under the Government of the Republic of Lithuania No. 63-23 (February 25, 2010) //

http://www.Irv.It/bylos/veikla/komisijos/saulelydzio/17_2010-1125_posedzio_protokolas.pdf (accessed May 31, 2011).

5. Minutes by the Sunset Commission under the Government of the Republic of Lithuania No. 63-5 (February 11, 2010) //

http://www.Irv.It/bylos/veikla/komisijos/saulelydzio/3_2010-0211_posèdžio_protokolas.pdf (accessed May 31, 2011).

6. Minutes by the Sunset Commission under the Government of the Republic of Lithuania No. 73-36 (18) (June 10, 2011) //

http://www.Irv.It/bylos/veikla/komisijos/saulelydzio/protokolas_09_06_10.pdf (accessed November 1, 2011).

7. Minutes by the Sunset Commission under the Government of the Republic of Lithuania for the year 2009-2011 // http://www.Irv.It/veikla/komisijos/saulelydzio-komisija/komisijos-veikla/ (accessed November 1, 2011).

8. Nutarimas dèl valstybès tarnybos tobulinimo koncepcijos patvirtinimo (Resolution on the Authorization of the Civil Service Improvement Strategy Conception). Project by the Government of the Republic of Lithuania No. 102142-01 (May 31, 2010) // 
http://www.Irs.It/pls/proj/dokpaieska.showdoc_l?p_id=37209\&p_query=\&p_tr $2=\& p \_o r g=\& p \_f i x=n \& p \_g o v=n$ (accessed September 14, 2011).

9. On the Programme of the Government of the Republic of Lithuania. Resolution of Seimas of the Republic of Lithuania No. XI-52 (December 09, 2008) // http://www.Irv.It/bylos/vyriausybes/en_15_programa.pdf (accessed November 1, 2011).

10. Valstybès tarnybos (iskaitant statutinę valstybès tarnybą) tobulinimo gairès (Working Document on the Improvement of Civil Service (Including the Statutory Civil Service)). Office of the Prime Minister of the Republic of Lithuania (May 20, 2011).

11. Valstybès tarnybos tobulinimo koncepcija (Civil Service Improvement Conception). Project by the Office of the Prime Minister of the Republic of Lithuania (March 01, 2010) //

http://www.Irs.It/pls/proj/dokpaieska.showdoc_I?p_id=22364\&p_org=18\&p_fi $\mathrm{x}=\mathrm{n} \& \mathrm{p} \_\mathrm{gov}=($ accessed May 31, 2011).

12. Valstybinio audito ataskaita: statutinès vidaus tarnybos valdymas (Report of the State Audit: Management of Statutory Civil Service). Report of the National Audit Office of Lithuania No. VA-P-40-3-2 (January 13, 2011) // www.vkontrole.It/failas.aspx?id=2301 (accessed May 3, 2011). 